\title{
DECISIONS
}

\section{Oral allergy syndrome}

\section{Gordon Sussman MD, Arthur Sussman MD, David Sussman H BMSc}

Previously published at www.cmaj.ca

\begin{abstract}
A 25-year-old man presents with itchiness in his mouth immediately after eating fruits such as apples, peaches and cherries. On a few occasions after eating peanuts and almonds, he also has felt tightness in his throat and a sensation that his throat was closing. He has a history of seasonal allergies (rhinorrhea and sneezing) in the early spring.
\end{abstract}

\section{Does this patient have food allergies?}

It appears that this patient is presenting with an allergy to fruits and nuts. However, he does not have a true food allergy; rather, he has pollen-food or oral allergy syndrome. His symptoms result from seasonal rhinorrhea (intermittent allergic rhinitis), an allergic reaction presenting with local IgE-mediated mast-cell activation causing rapid-onset tingling and pruritus of the lips, mouth and oropharynx. ${ }^{1.2}$ These symptoms, although usually short-lived and benign, can occasionally cause more severe allergic reactions if they are accompanied with pharyngeal swelling.

Most adult-onset food allergies are the result of cross-reactions between foods and inhaled allergens. ${ }^{3}$ Cross-reactivity is caused by IgE antibodies that can bind to pollen proteins and structurally similar food allergens (i.e., a pan-allergen). Therefore, cross-reactive epitopes can cause two clinical scenarios: hay fever triggered by pollens and associated food allergies. ${ }^{2}$

Table 1 summarizes common cross-reactive foods and their pollen analogues. ${ }^{1-6}$ Fruits associated with oral allergy syndrome are in the apple and plum families, but patients may also react to potatoes, carrots, celery, peanuts, hazelnuts and almonds. For example, the cross-reactivity between birch pollen and various foods is a consequence of a homology of various pathogen-related proteins. Mal d 1, the major apple allergen, is $63 \%$ homologous to Bet $\mathrm{v} 1$, the major birch pollen allergen. Other birch pollen-related proteins have been indentified in hazelnuts (Cor a 1), celery (Api g 1) and potatoes. ${ }^{5,6}$

Seasonal rhinorrhea in the early spring is most likely caused by allergies to tree pollens. Oral allergy syndrome occurs in $50 \%-70 \%$ of patients who are specifically sensitized to birch pollen. ${ }^{7.8}$ Given our patient's history of seasonal allergies in the early spring and the symptoms he has after eating some foods, it is likely that he has oral allergy syndrome.

\section{Are further investigations required?}

A diagnosis of oral allergy syndrome is based primarily on clinical history, but it should be confirmed by skin prick testing. ${ }^{1}$ In patients with allergies to airborne particles, itching or tingling in the mouth after eating fresh fruit or vegetables is enough to suspect oral allergy syndrome. Diagnosis can be delayed because the reaction to such foods will be inconsistent if the cross-reactive proteins have already been denatured, as in cooked, canned, pasteurized and frozen foods. Nut allergens, however, are generally not destroyed by these processes. Seasonal rhinorrhea may be overshadowed by reactions to raw fruit and nuts.

The commercially available fruit extracts used in allergy testing are not usually reliable indicators of allergy in patients with oral allergy syndrome, because the cross-reactive epitopes have been destroyed by the manufacturing process. ${ }^{1}$ Prick-plusprick testing (prick the fruit, then prick the skin) with freshly prepared fruit extracts is more sensitive in detecting allergenspecific IgE-antibody. In vitro IgE blood tests are available, but their sensitivity and specificity in patients with oral allergy syndrome require further confirmatory studies. ${ }^{2,45}$ Componentspecific diagnostic skin test reagents are not yet available.

\section{What treatment should be offered?}

The easiest and safest way to treat oral allergy syndrome is to recommend that the patient avoid the foods that cause the problem. Cross reactivity varies among patients. Only those foods causing the clinical allergy need to be avoided.

Oral allergy syndrome should be managed according to the clinical presentation. It is often more prominent during the specific season for airborne pollen that corresponds to the seasonal rise in related IgE antibodies. Most patients with seasonal allergic rhinitis can be treated with a combination of allergen avoidance and pharmacotherapy. ${ }^{9}$ Immunotherapy may be beneficial if a single allergen is implicated. ${ }^{8}$ Pollen-specific immunotherapy can be used to treat rhinosinusitis, conjunctivitis and asthma resulting from exposure to birch or tree pollen. ${ }^{8,10}$

From the Department of Medicine, University of Toronto, and the Division of Allergy, Clinical Immunology, St. Michael's Hospital, (G. Sussman); Mount Sinai Hospital (A. Sussman), Toronto, Ont.; and the University of Toronto, Toronto, Ont. (medical student) (D. Sussman)

CMAJ 2010. DOI:10.1503/cmaj.090314 
Table 1: Types of pollen and food associated with oral allergy syndrome $e^{1-6}$

\begin{tabular}{llll}
\hline Pollen & \multicolumn{1}{c}{ Fruit } & \multicolumn{1}{c}{ Vegetables/spices } & Nuts/seeds/legumes \\
\hline $\begin{array}{l}\text { Alder } \\
\text { Birch }\end{array}$ & $\begin{array}{l}\text { Apples, cherries, peaches, pears } \\
\text { Kiwi, apples, pears, plums, } \\
\text { peaches, nectarines, apricots, } \\
\text { cherries, tomatoes }\end{array}$ & $\begin{array}{l}\text { Parsley, celery } \\
\text { Celery, carrots, potatoes, } \\
\text { parsnips, green peppers, dill, } \\
\text { cumin, peas, cilantro, fennel }\end{array}$ & $\begin{array}{l}\text { Hazelnuts, walnuts, almonds, } \\
\text { peanuts, lentils, beans } \\
\text { tomatoes }\end{array}$ \\
\hline Grass & Potatoes & Peanuts \\
Mugwort* & $\begin{array}{l}\text { Watermelon, cantaloupe, } \\
\text { honeydew, bananas }\end{array}$ & $\begin{array}{l}\text { Celery, carrots, dill, parsley, } \\
\text { fennel, coriander, cumin } \\
\text { Zucchini, cucumbers, squash }\end{array}$ & Sunflower seeds \\
\hline Ragweed & & & \\
\hline
\end{tabular}

*Also associated with honey.

In our patient, treatment with tree-pollen-specific immunotherapy for hay fever may decrease the associated food allergies. Patients have anecdotally indicated a decreased severity of symptoms related to oral allergy syndrome after immunotherapy or during seasons with lower pollen counts. However, a review of studies on the effect of pollen-specific immunotherapy on oral allergy syndrome has shown variable outcomes. ${ }^{11}$ In addition, if patients outgrow their inhalant allergies, there may be a higher threshold or disappearance of reactions to the foods that cause oral allergy syndrome.

Our patient has symptoms caused by an allergy to raw apples, peaches and cherries. He should avoid these fruits; however, he may be able to eat them if they are cooked. A self-injected epinephrine device is not generally needed for oral allergy syndrome. However, because our patient presented with a feeling of tightness in his throat, such a device was prescribed.

For more information on the diagnosis and management of intermittent allergic rhinitis, see CMAJ 2010;182:935-7. ${ }^{9}$

This article has been peer reviewed.

Competing interests: None declared.

\section{REFERENCES}

1. Adkinson F Jr, Bochner B, Busse W, et al., editors. Middleton's allergy principles and practice. 7th ed. Philadelphia (PA): Mosby Elsevier; 2008.

2. Mari A, Ballmer-Weber B, Vieths S. The oral allergy syndrome: improved diagnostic and treatment methods. Curr Opin Allergy Clin Immunol 2005;5:267-73.

3. Pong AH. Oral allergy syndrome. Vaughan (ON): Allergy/Asthma Information Association (AAIA); 2000. Available: www.calgaryallergy.ca/Articles/English /Oral_Food_Allergy.htm (accessed 2009 Dec. 3).

4. Vieths S, Scheurer S, Ballmer-Weber B. Current understanding of cross-reactivity of food allergens and pollen. Ann N Y Acad Sci 2002;964:47-68.

5. Eriksson NE, Formgren H, Svenonius E. Food hypersensivity in patients with pollen allergy. Allergy 1982;37:437-43.

6. Sloanne D, Sheffer A. Oral allergy syndrome. Allegy Asthma Proc 2001;22:321-5.

7. Mogensen JE, Wimmer R, Larsen JN, et al. The major birch allergen, Bet v 1 shows affinity for a broad spectrum of physiological ligands. J Biol Chem 2002; 277:23684-92.

8. Hoffmann-Sommergruber K, O'Riordain G, Ahorn H, et al. Molecular characterization of Dau c 1, the Bet v 1 homologous protein from carrot and its cross-reactivity with Bet and Api g 1. Clin Exp Allergy 1999; 29:840-7.

9. Sussman G, Sussman D, Sussman A. Intermittent allergic rhinitis. CMAJ 2010; 182:935-7.

10. Marcucci F, Frati L, Sensi G, et al. Evaluation of food-pollen cross-reactivity by nosemouth cross-challenge in pollinosis with oral allergy syndrome. Allergy 2005;60:501-5.

11. Bucher X, Pichler JW, Dahinden CA, et al. Effect of tree pollen specific, subcutaneous immunotherapy on the oral allergy syndrome to apple and hazelnut. Allergy 2004;59:1272-6.

Correspondence to: Dr. Gordon Sussman, University of Toronto, 202 St. Clair Ave. W, Toronto ON M4V 1R2; gsussman@rogers.com 